\title{
Anatomical UV exposure in French outdoor workers
}

\author{
David VERNEZ, PhD 1. *, Alice KOECHLIN, Ing 2,3, Antoine MILON, MSc 1, Magali
}

BONIOL, MSc 3, Faustine VALENTINI, MSc 3, Marie-Christine CHIGNOL, MSc 4, Jean-

Francois DORE, PhD 4, Jean-Luc BULLIARD, PhD 5, Mathieu BONIOL, PhD 1,2,

1. Institute of Work and Health (IST), University of Lausanne and Geneva, Lausanne, Switzerland.

2. Strathclyde Institute of Global Public Health at iPRI, Lyon, France

3. International Prevention Research Institute, iPRI, Lyon, France

4. Centre de Recherche en Cancérologie de Lyon, UMR Inserm U1052 - CNRS U5286, Lyon, France

Cancer Epidemiology Unit, Institute of Social and Preventive Medicine, Lausanne

University Hospital, Lausanne, Switzerland

\section{Corresponding author*}

Corresponding author: Prof. David Vernez, Institute of Work and Health (IST), rte de la Corniche 2, 1033 Epalinges-Lausanne, Switzerland (David.Vernez@hospvd.ch)

\section{Conflict of interest}

The authors declare no conflicts of interest.

\section{Funding}

This work was supported by a research grant from ANSES N.EST-2011/1/075

(principal investigator: David Vernez). 


\section{Running title}

Anatomical UV exposure

\section{Abstract}

\section{Background.}

Solar UV has been recognized as the main causative factor for skin cancer and is currently classified as a carcinogenic agent by IARC.

\section{Method}

Results from a previous phone survey conducted in 2012 in France were used to assess exposure conditions to sun among outdoor workers. Satellite data was used in combination with an exposure model to assess anatomical exposure.

\section{Result}

The yearly median exposure of the outdoor worker population is $77-116 \mathrm{~kJ} / \mathrm{m}^{2}$. Road workers, building workers and gardeners are the more exposed. About $70 \%$ of the yearly dose estimate is due to the cumulative summer and spring exposures.

\section{Conclusion}

This study highlights the role of individual factors in anatomical exposure and ranks the most exposed body parts and outdoor occupations. Prevention messages should put emphasis on spring exposure, which is an important contributor to the yearly dose. 


\section{Introduction}

Solar ultraviolet (UV) has been recognized as the main causative factor for skin cancer (1). Each year, excessive sun exposure leads to an estimated 60,000 premature skin cancer deaths worldwide, the majority of these being malignant melanomas (MM). Although epithelial skin cancer is less severe than melanoma, it is the most common cancer in fair-skinned populations with an annual burden of about 13 million new cases worldwide (basal cell carcinomas (BCC) $78 \%$, squamous cell carcinomas (SCC) $22 \%)(2)$. SCC has been associated with chronic sun exposure while MM has been associated with intermittent skin exposure. Both chronic (cumulative) and intermittent exposures seems to be paying a role in BCC occurrence $(3,4)$.

The dose-response between UV exposure patterns and skin cancer occurrence is however not yet fully understood. High inter- and intra-individual (anatomical) variations in UV doses received make exposure assessment challenging and little individual exposure data is available $(5,6)$. Consequently, epidemiological evidence is based on crude exposure indicators. Acute exposure is often assessed though sunburns history, while ground irradiance data is, at best, used to assess chronic exposure. Moreover, both BCC and SCC, which are less severe than MM, are seldom recorded in a systematic way.

Despite of these limitations, the level of awareness for UV risks has increased dramatically over the last 10 years among the public, the experts and the authorities. Solar UV has been classified radiation as group \#1 carcinogen in 2009 by the

International Agency for Research on Cancer (IARC) (7). Public and occupational 
exposure limits, such as the daily $(8 \mathrm{~h})$ maximum of $30 \mathrm{~J} . \mathrm{m}^{-2}(0.3 \mathrm{SED})$ recommended by the International Commission on Non-Ionizing Radiation Protection (ICNIRP), have been adopted in several countries (8). According to the European Agency for Safety and Health at work (EU-OSHA), solar UV is also, in terms of prevalence, the first carcinogenic agent at the workplace. It is currently estimated that 14.5 million workers in the European Union are exposed to solar UV at least $75 \%$ of their working time (9). Recently, the German authorities added the "skin cancer as a result of exposure to UV radiation" to the official list of occupation diseases (10).

The increasing awareness for solar UV risks put emphasis on the need to better document and understands exposure patterns during outdoor activities. In this study, results of a survey previously conducted among outdoor workers in France were used to estimate anatomical exposure to erythemal UV. 


\section{Methods}

\section{Estimating anatomical doses}

Results from a previous phone survey among outdoor workers were used to assess, through modelling, exposure doses to solar UV radiation. Detailed information about the survey conducted as well as the regression model used to assess exposure are available in previous publications $(11,12)$.

In brief, the survey was performed in France in 2012 on a sample of workers aged 25 to 69 years and reporting at least one year of occupational UV exposure during the past five years and for more than one day per week for solar radiation. 889 out of the 3,167 individuals interviewed reporting exposure to solar UV radiation and for which an average daily UV radiation exposure could be estimated were included in the study. The interview recorded information on occupational UV exposure with description of sector, job description as well as time of the day when job started and ended and total daily duration of outdoor activity. For each individual, the current place of residence was geolocalised based on post codes from the French National Institute of Statistics and Economic Studies (INSEE). These longitude and latitude were used to retrieve average daily UV radiation data for the 2003-2007 periods from the EuroSun database. Ambient irradiance data were used to assess the UV radiation that workers could have experienced during their work activity.

The regression model was built on data issued from the SimUVEx (Simulating UV Exposure, v1.0) 3D numeric model (13). SimUVEx allows the prediction of the dose and anatomical distribution of UV exposure received on the basis of ground irradiation and 
morphological data. Ground irradiation data for the entire year 2012 (527 040 measurements, 1 measurement per minute) was obtained from the MeteoSwiss Payerne station $\left(46.815^{\circ} \mathrm{N}, 6.944^{\circ} \mathrm{E}\right.$, altitude $\left.491 \mathrm{~m}\right)$. This facility measures ambient direct, diffuse, and reflected UV irradiance concomitantly using erythemally-weighted broadband UV radiometers (biometer 501A by Solar Light).

Exposures ratios ER [\%] (percent ambient exposure) for an adult male, performing an outdoor activity between 8 am and 5 pm, were computed. It was assumed that no shading or protective clothing was used and that the orientation to sun was changing. The analysis of simulation results evidenced that two input variables were sufficient to predict seasonal or annual ER $\left(\mathrm{R}^{2}=0.988\right)$ : the cosine of the maximal daily solar zenith angle and the fraction of the sky visible from the body site according to SimUVEx (11).

The regression model predicting ER is used to estimate exposure doses for a given individual $\mathrm{i}$ and anatomical site $\mathrm{x}\left(\mathrm{E}_{\mathrm{ix}}\right)$ according to equation 1 .

$$
\boldsymbol{E}_{\boldsymbol{i x}}=\boldsymbol{A}_{\boldsymbol{i}} \cdot \boldsymbol{F}_{\boldsymbol{a}} \cdot \boldsymbol{E} \boldsymbol{R}_{\boldsymbol{x} \boldsymbol{a}} \quad\left[\mathrm{J} / \mathrm{m}^{2}\right] \quad \text { Equation } 1
$$

Where, $A_{i}\left[\mathrm{~J} / \mathrm{m}^{2}\right]$ is the ambient irradiance endured by an individual $\mathrm{i}$ according to its residential location; $\mathrm{Fa}_{\mathrm{a}}[\%]$ is a correction factor taking into account the time spent outdoor during an occupational activity a; and $\mathrm{ER}_{\mathrm{xa}}[\%]$ is the exposure ratio for a given anatomical site $\mathrm{x}$ and occupational activity $\mathrm{a}$. 
Job description and daily exposure durations collected during the phone survey were used to set $F_{a}$. The proportion of UV corresponding to declared times/durations of exposure were computed for each subject using reference daily UV curves (average of 5 clear-sky days per season) issued from the HelioClim3 database (http://www.sodais.com/eng/index.html). $F_{a}$ was expressed as the ratio of ambient UV during the exposed period to the ambient UV over the whole reference day.

\section{Exposure scenarios}

Ambient irradiance $\left(A_{i}\right)$ and correction factor $\left(F_{a}\right)$ can easily be obtained from the survey results. The exposure ratio (ER) is however dependant on the body posture and thus requires a specific exposure scenario. Most of the job categories were too broad to be associated with a given postural activity. This is for instance the case for the "leisure and sport worker" category, which includes occupations such as ski teacher, football coach or tour guide. For some specific occupations, for which a regular postural pattern was expected, a specific postural scenario was used. This is the case for agricultural workers and building workers, whose postural activity has been investigated in previous studies $(6,14)$. Additionally, field observations of 2-4 worker-day, were conducted among gardeners/landscapers, mail carriers, horticulturists and child care workers. A broad "all workers" category was built to cover other outdoor occupations. A $100 \%$ "standing erect arms down" postural scenario was assumed for this category. Although this scenario is a crude simplification of complex and various occupational activities, it allows taking into account a wide range of occupations. Moreover, the "standing arms down" 
posture was found to be present in all outdoor activities and predominant among some occupations such as building workers (6). In order to assess the importance of body posture on the anatomical exposure, a 100'\% "standing bowing" scenario was also considered considered for the "all-workers". Table 1 summarizes the postural scenarios considered in different occupations.

Table 1 about here

\section{Exposed population}

The outdoor workers population investigated has been previously described (12). In brief, a total of 998 workers were considered as exposed to UV radiation. 889 individuals reporting exposure to solar UV radiation, for which an average daily UV radiation exposure could be estimated, were included in this study. The majority $(63 \%)$ were men with a median age of 41 years (interquartile range 33 to 50 ). A minority of participants (34\% often or always) had to take lunch outdoors because of their occupation. These workers were more exposed to UV radiation than others. The five more frequent job categories, according to the the International Standard Industrial Classification of All Economic Activities (ISIC, 4th revision), with outdoor sun exposure were gardeners, landscapers, construction workers, others, agricultural workers, culture, art, social workers, and industry workers. The culture, art, social workers categories include a wide range of occupations, such as journalist or street artists, which could be regularly exposed to solar UV. 



\section{Results}

A summary of the yearly doses estimates obtained for different occupations and body sites is shown in table 2. Anatomical doses are expressed as average values on a specific body site. A detailed view of the body sites considered is available in supplementary material (Figure S1). The estimated doses should be considered as upper estimates as no shade or protective clothing was considered. Overall, the yearly median exposure of the outdoor worker population ranges between 77 and $116 \mathrm{~kJ} / \mathrm{m}^{2}$, depending on the body site. A factor three is typically found between the $1^{\text {st }}$ and $3^{\text {rd }}$ quartile, suggesting a high inter-individual variability among the population of outdoor workers.

Table 2 about here

As illustrated in Figure 1, both anatomical site and occupation play an important role in the dose estimates. When considering a vertical body site, such as the face (Figure $1 \mathrm{a}$ ), the road and building workers appear to be the most exposed. They are followed by mail carriers, agricultural workers, gardeners, horticulturists and child care workers. This ranking changes when considering more horizontal or oblique body sites such as the neck or the top of shoulders (Figure $1 \mathrm{~b}, \mathrm{c}$ ). For these sites, the gardeners appear to be the most exposed, while the mail carriers fall back in the second last position.

Figure 1. Estimated erythemal UV dose, expressed as yearly erythemal UV dose (in $\mathrm{kJ} / \mathrm{m2}$ ) [median (interquartile range)] by occupation. 

a) Face exposure
b) Neck exposure
c) Top of shoulders exposure

The atypical exposure estimates obtained for the gardeners could be further illustrated by comparing body sites. As shown in Figure 2 (a), upper body sites, such as neck, skull and shoulders are the more exposed in the general outdoor workers population. The anatomical differences appears however relatively small compared to the interindividual variability. Similar results were found for most occupations (results not shown). As shown in Figure 2 (b) differences between body sites are however more pronounced for gardeners. The face exposure for gardeners $78(56-93) \mathrm{kJ} / \mathrm{m}^{2}$ falls for instance well below the exposure of other body parts.

Figure 2. Estimated erythemal UV dose, expressed as yearly erythemal UV dose (in $\mathrm{kJ} / \mathrm{m} 2$ ) [median (interquartile range)] by body site.

\section{a) All workers combined \\ b) Gardeners}

Exposure estimates split by season are available in supplementary material (table S1). An overview of these results, for selected body parts, is shown in figure 3 . Unsurprisingly, the summer exposure is the main contributor to the yearly dose. It is however closely followed by the spring exposure contribution. The spring contribution 
to the yearly exposure is above $30 \%$. Overall, about $70 \%$ of the yearly dose estimate is due to the cumulative summer and spring exposures. Little variation between anatomical sites and occupations is observable.

Figure 3. Estimated erythemal UV dose for all workers, expressed as yearly erythemal UV dose (in $\mathrm{kJ} / \mathrm{m} 2$ ) [median (interquartile range)] by body site and by season. 


\section{Discussion}

Several studies have estimated the UV exposure of outdoor workers. Both simulations and field measurements evidenced exposures beyond the threshold recommended by the International Commission on Non-Ionizing Radiation Protection (ICNIRP). Due to the lack of available exposure data, little is known however about the precise exposure patterns and factors among these populations. This study enabled to estimate anatomical exposure to solar UV among a sample of French outdoor workers. Detailed exposure scenarios were built for some specific occupations, allowing ranking the more exposing activities, exposing periods or the more exposed anatomical sites.

As expected, the full time outdoor occupations such as agricultural or building workers or gardeners are more exposed. The large variety of exposure conditions (environment, exposure periods, postural activity) observed in the survey suggests however that significant exposure could also be endured among other occupations (e.g. mail carriers, child care workers). Moreover the ranking of exposure appears to be dependent on the body site. While the building workers were the most exposed according to the face dose estimate, the gardeners were the most exposed according to the neck dose estimate. The difference in the anatomical exposure pattern found for gardeners could be explained by the difference in postural activity and exposure periods to sun.

Both environmental and individual factors appear to play an important role in anatomical exposure, as illustrated by the observed variability between seasons, occupations and body site, respectively. Differences in occupations, which are explained by differences in working periods, postural scenario and location are noteworthy. The 
environmental variability considered in this study is limited to the latitude and altitude ranges as well as weather conditions existing in mainland France. Countries located at higher or lower latitude could for instance be exposed to significantly different ambient irradiance conditions. Moreover, because the ER model does not adequately reflects exposure in snow-covered environments, exposures in high altitude or areas with regular snow cover will be underestimated. These reported exposures only apply for a temperate climate in Europe such as France and should be considered as upper estimates as shading provided by the environment (e.g. trees, buildings) or protective clothing (e.g long sleeves, hats) was not considered. It is beyond the scope of the present article to describe outdoor exposure in other populations and under different climatic situations. Such other situations will likely be really different in term of UV dose and anatomical distribution because of different climatic situation, activity sectors, and schedule of work.

For a same body site, the variation coefficient range between different outdoor occupations, in annual dose, is $29-37 \%$. The role of the postural scenario could be further illustrated by comparing the "all workers (100\% erect)" and "all workers (100\% bowing)" scenarios. The change in position of the upper body leads to a decrease or increase by a factor 0.5-2.5.

Exposure to sun during spring is a concern in outdoor occupational activities. While the workers' awareness and the prevention messages are focused on summer, during which the direct UV radiation is the most important, spring exposure could be underestimated and prevention measures inadequate. The contribution of spring appears to be only 10 
to $30 \%$ lower than the contribution of summer. Several factors could explain this (i) most of the body sites are not horizontally oriented and thus more prone to be exposed when the sun is not at its highest zenith position; (ii) work during the hottest periods (around lunch in Summer) is uncomfortable and avoided when possible by regular outdoor workers; and (iii) as shown previously (15), the diffuse light component is the major contributor to the yearly dose. The "peak" period for diffuse exposure is not limited to the summer period. The lack of awareness for spring occupational UV exposure is of particular concern because it is tempting to seize the opportunity of the first warm days after the winter to remove as much protective clothing as possible. Moreover, early in the year, the skin has not been tanned and is prone to develop sunburns.

Absolute doses estimates have to be considered carefully because no protective clothing or shade was considered in the model. It is therefore an upper estimate and real exposure is likely lower. The relative ranking of occupations and body sites is however of prime interest in primary prevention. It highlights the need to target some occupations and design preventive measures adequate to the specific needs (e.g skin cancer screening, protective clothing targeted to the most exposed body sites). Moreover, it shows that environmental conditions (ambient radiation) and exposure scenario (postural activity, exposure periods) have to be considered carefully in order to assess exposure doses. Although exposure measurements are advocated when possible, exposure estimates through models are of importance when dealing with large number 
of exposures or when only retrospective assessments are possible (e.g. the contribution of work exposure in a patient with skin cancer).

\section{Acknowledgements:}

This work was supported by a research grant from ANSES N.EST-2011/1/075 (principal investigator: David Vernez).

We declare no conflict of interest.

All authors had full access to all the data in the present study and take responsibility for the integrity of the data and the accuracy of the data analysis. 


\section{References}

1. Lucas R. Solar Ultraviolet Radiation: Assessing the environmental burden of disease at national and local levels. Geneva: WHO, World Health Organization, 2010.

2. Lucas RM, McMichael AJ, Armstrong BK, Smith WT. Estimating the global disease burden due to ultraviolet radiation exposure. International Journal of Epidemiology. 2008;37(3):654-67.

3. Kricker A, Armstrong BK, English DR. Does intermittent sun exposure cause basal cell carcinoma? a case-control study in Western Australia. International Journal of Cancer. 1995;60(4):489-94.

4. Bauer A, Diepgen TL, Schmitt J. Is occupational solar ultraviolet irradiation a relevant risk factor for basal cell carcinoma? A systematic review and meta-analysis of the epidemiological literature. British Journal of Dermatology. 2011;165(3):612-25.

5. Wright C, Diab R, Martincigh B. Anatomical distribution of ultraviolet solar radiation. South Afr J Sci. 2004;100(9-10):498-500.

6. Milon A, Sottas P-E, Bulliard J-L, Vernez D. Effective exposure to solar UV in building workers: influence of local and individual factors. Journal of Exposure Science and Environmental Epidemiology. 2007;17(1):58-68.

7. El Ghissassi F, Baan R, Straif K, Grosse Y, Secretan B, Bouvard V, et al. A review of human carcinogens. Part D: radiation. The Lancet Oncology. 2009;10(8):751-2. 
8. International Commission on Non-ionizing Radiation Protection (ICNIRP). Guidelines on limits of exposure to ultraviolet radiation of wavelengths between $180 \mathrm{~nm}$ and $400 \mathrm{~nm}$ (incoherent optical radiation). Health Physics. 2004;87:171-86.

9. New and emerging risks in occupational safety and health Luxembourg: European Agency for Safety and Health at Work, 2009.

10. Schmitt J, Seidler A, Diepgen TL, Bauer A. Occupational ultraviolet light exposure increases the risk for the development of cutaneous squamous cell carcinoma: a systematic review and meta-analysis. British Journal of Dermatology. 2011;164(2):291307.

11. Vernez D, Milon A, Vuilleumier L, Bulliard J-L, Koechlin A, Boniol M, et al. A general model to predict individual exposure to solar UV by using ambient irradiance data. J Expos Sci Environ Epidemiol. 2014.

12. Boniol $M$, Koechlin A, Valentini F, Chignol M-C, Dore J-F, Bulliard J-L, et al. Occupational UV Exposure in French Outdoor Workers. J Occup Environ Med 2015; [in press - accepted for publication].

13. Vernez D, Milon A, Francioli L, Bulliard JL, Vuilleumier L, Moccozet L. A Numeric Model to Simulate Solar Individual Ultraviolet Exposure. Photochemistry and Photobiology. 2011;87:721-8.

14. Milon A, Bulliard J-L, Vernez D, editors. Occupational exposure to solar UV and protective habits in agriculture [Abstract]. Health, Work and Social Responsibility : the occupational hygienist and the integration of environment, health and safety : IOHA 
2010, 8th International Scientific Conference; 201028 September - 2 October 2010;

Roma, Italy: INAIL.

15. Vernez D, Milon A, Vuilleumier L, Bulliard JL. Anatomical exposure patterns of skin to sunlight: relative contributions of direct, diffuse and reflected ultraviolet radiation. British Journal of Dermatology. 2012;167(2):383-90. 


\section{Tables}

Table 1. Postural scenario considered by occupation (\% of work time)

\begin{tabular}{|c|c|c|c|c|c|c|}
\hline Profession & $\begin{array}{c}\text { Number of } \\
\text { subjects }\end{array}$ & Seated & Kneeling & $\begin{array}{l}\text { Standing erect } \\
\text { arms down }\end{array}$ & $\begin{array}{l}\text { Standing erect } \\
\text { arms up }\end{array}$ & Standing bowing \\
\hline Agricultural workers & 108 & 25 & 4 & 30 & 15 & 26 \\
\hline Child care workers & 18 & 0 & 10 & 90 & 0 & 0 \\
\hline Building workers & 126 & 4 & 6 & 79 & 4 & 6 \\
\hline Landscapers/gardeners & 23 & 1 & 18 & 35 & 1 & 45 \\
\hline Mail carriers & 97 & 85 & 0 & 15 & 0 & 0 \\
\hline Road workers & $126^{*}$ & 0 & 3 & 80 & 5 & 12 \\
\hline Horticulturists & $108^{*}$ & 5 & 25 & 25 & 5 & 40 \\
\hline All workers (erect) & 889 & 0 & 0 & 100 & 0 & 0 \\
\hline All workers (bowing) & 889 & 0 & 0 & 0 & 0 & 100 \\
\hline
\end{tabular}

*: data from all Building workers (resp. all Agricultural workers) were used for road workers (resp. Horticulturists) because of the impossibility to separate road workers (resp. Horticulturists) from other building workers (resp. Agricultural workers). 
Table 2. Estimated yearly erythemal UV dose for the face, expressed as yearly erythemal UV dose (in $\mathrm{kJ} / \mathrm{m} 2$ ) [median (interquartile range)] by occupation and body site.

\begin{tabular}{|c|c|c|c|c|c|c|c|}
\hline & $\begin{array}{c}\text { Agricultural } \\
\text { workers }\end{array}$ & $\begin{array}{c}\text { Child care } \\
\text { workers }\end{array}$ & $\begin{array}{l}\text { Building } \\
\text { workers }\end{array}$ & $\begin{array}{c}\text { Landscapers, } \\
\text { gardeners }\end{array}$ & Mail carriers & Road workers & Horticulturists \\
\hline Face & 82 (58-105) & $34(23-50)$ & $109(73-128)$ & 78 (56-93) & $89(67-124)$ & $106(71-124)$ & $63(45-81)$ \\
\hline Skull & $126(90-162)$ & $48(32-69)$ & 155 (103-181) & 166 (118-196) & 97 (73-135) & 155 (104-182) & $133(95-172)$ \\
\hline $\begin{array}{l}\text { Forearm } \\
\text { (external) }\end{array}$ & $117(83-150)$ & $38(26-56)$ & $128(86-150)$ & $143(102-170)$ & $103(78-143)$ & $128(86-150)$ & $117(83-151)$ \\
\hline $\begin{array}{l}\text { Upper arm } \\
\text { (external) }\end{array}$ & $113(80-145)$ & $36(24-53)$ & $121(81-142)$ & $141(101-168)$ & $86(65-120)$ & $122(82-143)$ & 117 (83-151) \\
\hline Neck back & $144(102-185)$ & $54(36-78)$ & $174(117-204)$ & $197(141-234)$ & $102(77-141)$ & $176(118-206)$ & $160(113-205)$ \\
\hline $\begin{array}{l}\text { Top of } \\
\text { shoulders }\end{array}$ & $112(79-144)$ & $37(25-54)$ & 125 (84-147) & 167 (119-198) & $63(48-88)$ & $132(88-154)$ & $130(92-167)$ \\
\hline Shoulder & $134(95-173)$ & 49 (33-71) & 159 (107-186) & $161(115-192)$ & $115(87-160)$ & 159 (107-186) & 131 (93-169) \\
\hline $\begin{array}{l}\text { Upper Leg } \\
\text { (front) }\end{array}$ & $107(76-138)$ & $39(26-56)$ & $126(84-148)$ & $117(84-140)$ & $108(82-150)$ & $124(83-145)$ & $96(68-124)$ \\
\hline $\begin{array}{l}\text { Lower leg } \\
\text { (back) }\end{array}$ & 94 (67-121) & $39(26-57)$ & $124(83-145)$ & $132(94-156)$ & $59(45-82)$ & $125(83-146)$ & $107(76-138)$ \\
\hline Ambient & $212(151-273)$ & 80 (54-117) & $258(173-302)$ & $262(187-310)$ & 175 (133-244) & $258(173-302)$ & $212(151-273)$ \\
\hline
\end{tabular}

\begin{tabular}{cc}
\hline $\begin{array}{c}\text { All workers } \\
\text { (erect) }\end{array}$ & $\begin{array}{c}\text { All workers } \\
\text { (bowing) }\end{array}$ \\
\hline $79(39-117)$ & $32(16-48)$ \\
$104(52-156)$ & $116(58-173)$ \\
$84(42-125)$ & $106(53-158)$ \\
$77(39-115)$ & $105(53-157)$ \\
$116(58-173)$ & $139(70-207)$ \\
$82(41-122)$ & $148(74-220)$ \\
$108(54-161)$ & $109(55-163)$ \\
$86(43-129)$ & $73(37-109)$ \\
$84(42-125)$ & $84(42-126)$ \\
$176(88-262)$ & $176(88-262)$ \\
\hline
\end{tabular}




\section{Figures}
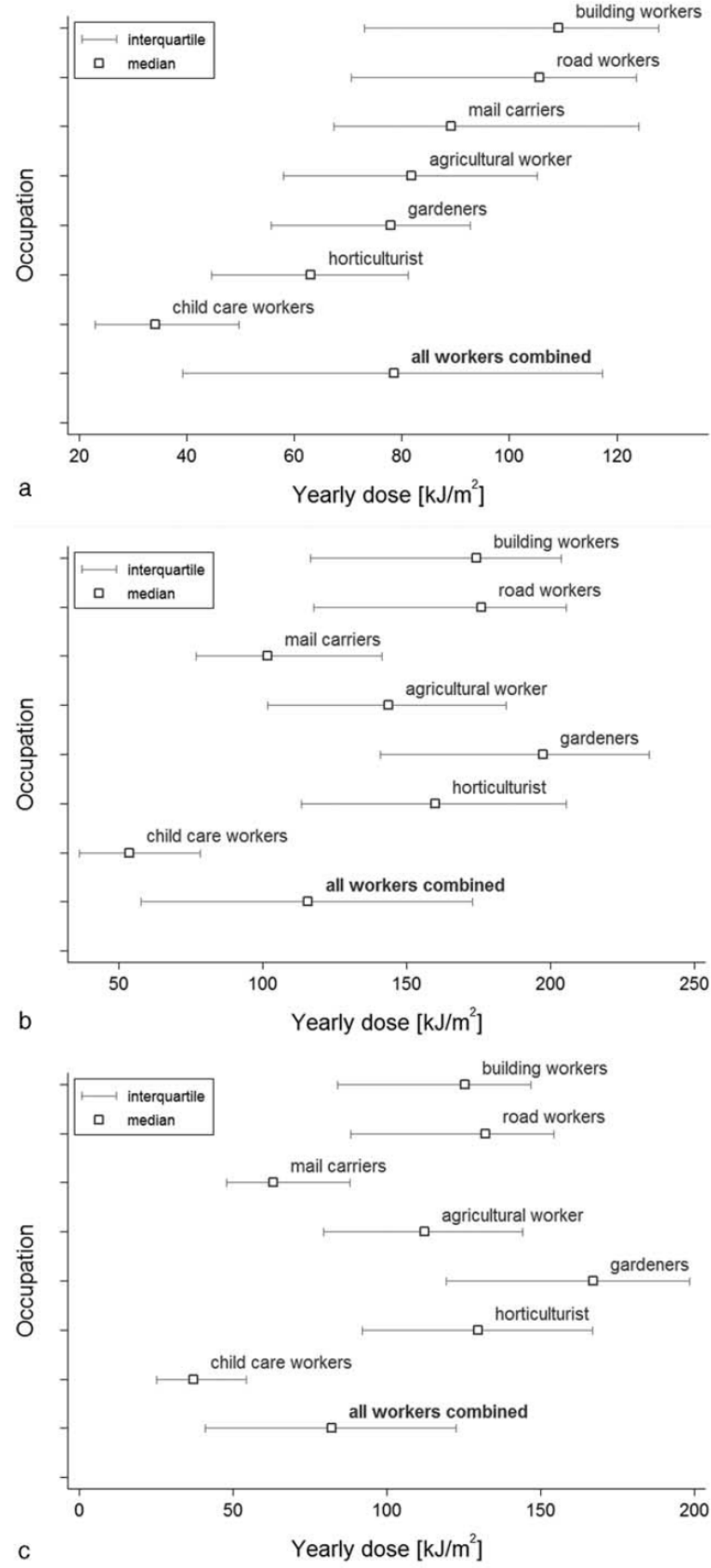

Figure 1. 


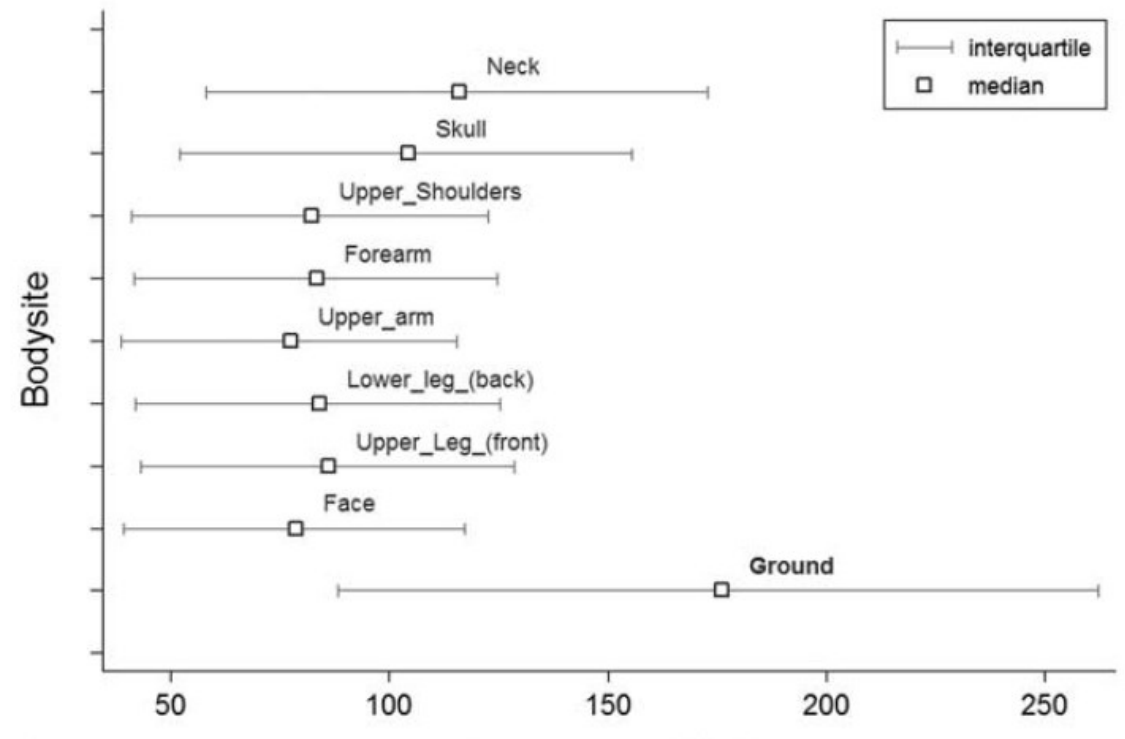

a

Yearly dose $\left[\mathrm{kJ} / \mathrm{m}^{2}\right]$

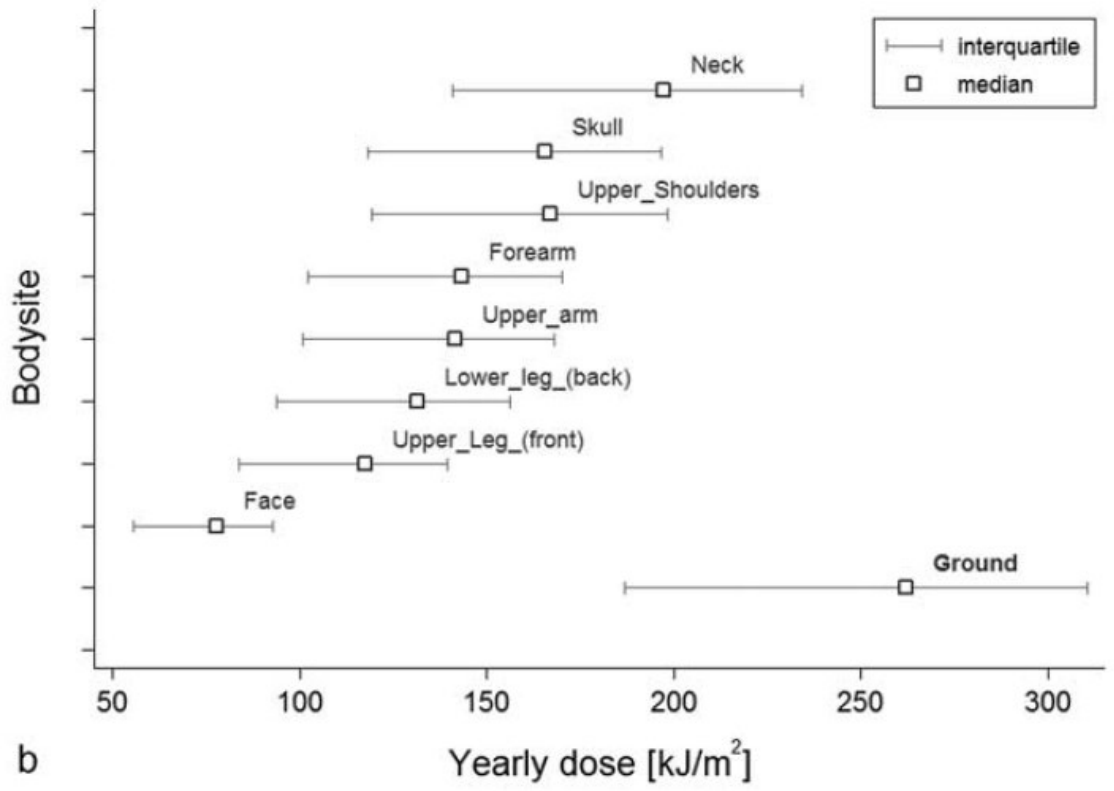

Figure 2. 


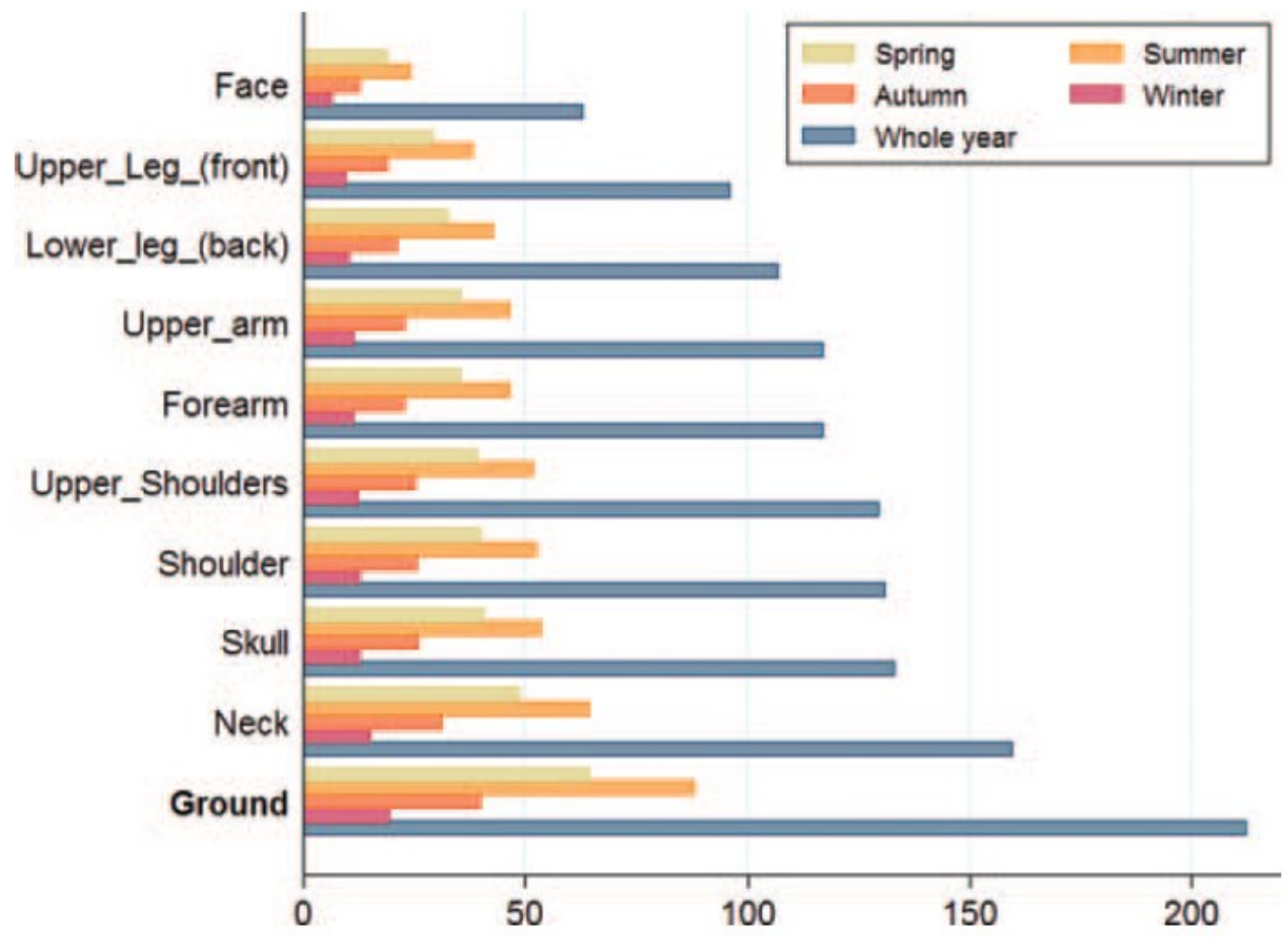

Figure 3. 


\section{Supplementary material}

Figure S1. View of the numeric manikin (standing arms down posture) and location of the main anatomical sites investigated.
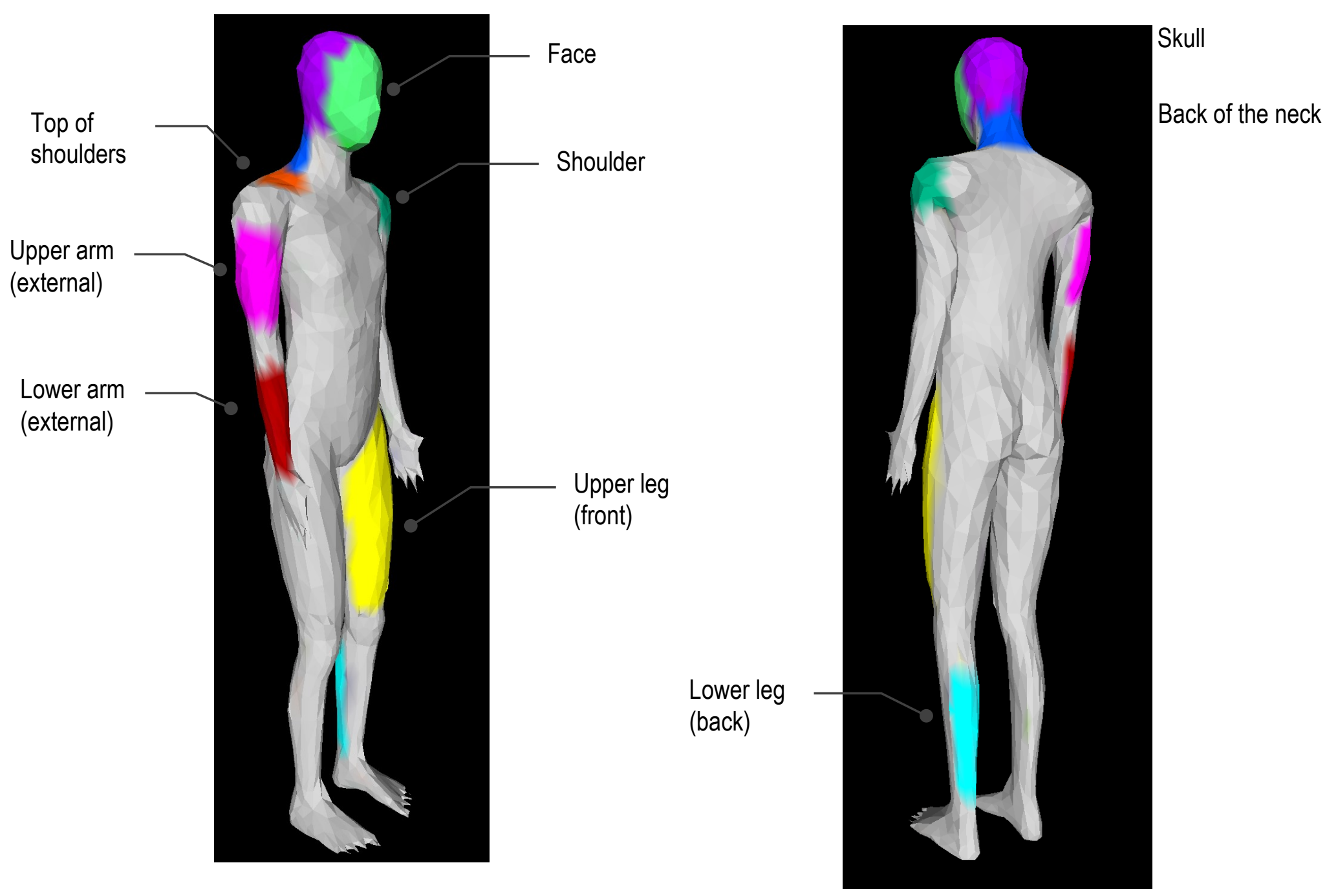
Table S1 Estimated seasonal erythemal UV dose, expressed erythemal UV dose (in $\mathrm{kJ} / \mathrm{m} 2$ ) [median (interquartile range)] by occupation and body site.

a) Spring (March, April, May)

\begin{tabular}{|c|c|c|c|c|c|c|c|c|c|}
\hline & $\begin{array}{c}\text { Agricultural } \\
\text { workers }\end{array}$ & $\begin{array}{c}\text { Child care } \\
\text { workers }\end{array}$ & $\begin{array}{l}\text { Building } \\
\text { workers }\end{array}$ & $\begin{array}{c}\text { Landscapers, } \\
\text { gardeners }\end{array}$ & Mail carriers & Road workers & Horticulturists & $\begin{array}{c}\text { All workers } \\
\text { (erect) }\end{array}$ & $\begin{array}{c}\text { All Worker } \\
\text { (bowing) }\end{array}$ \\
\hline Face & $25(18-33)$ & $11(9-15)$ & $34(24-38)$ & $24(17-28)$ & $28(19-39)$ & $33(23-37)$ & $19(14-25)$ & $25(13-37)$ & $10(5-15)$ \\
\hline Skull & $39(27-50)$ & $16(12-21)$ & $49(33-54)$ & $52(36-59)$ & $30(21-42)$ & $49(34-54)$ & $41(29-53)$ & $33(17-49)$ & $36(19-54)$ \\
\hline Forearm (external) & $36(25-46)$ & $13(10-17)$ & $40(28-45)$ & $45(31-51)$ & $32(22-45)$ & $40(28-45)$ & $36(25-47)$ & $26(14-39)$ & $33(17-49)$ \\
\hline Upper arm (external) & $34(24-45)$ & $12(9-16)$ & $38(26-42)$ & $44(31-51)$ & 27 (19-38) & $39(26-43)$ & $36(25-47)$ & $24(13-36)$ & $33(17-49)$ \\
\hline Neck back & $44(31-57)$ & $18(14-24)$ & $55(38-61)$ & $62(43-71)$ & $32(22-44)$ & $56(38-61)$ & $49(35-64)$ & $36(19-54)$ & $44(23-66)$ \\
\hline Top of shoulders & $34(24-45)$ & $13(10-17)$ & $40(27-44)$ & $52(36-60)$ & $20(14-28)$ & $42(28-46)$ & $40(28-52)$ & $26(13-38)$ & $46(24-69)$ \\
\hline Shoulder & $41(29-53)$ & $16(12-22)$ & $50(34-56)$ & $51(35-58)$ & $36(25-50)$ & $50(34-55)$ & $40(29-52)$ & $34(18-50)$ & $34(18-51)$ \\
\hline Upper Leg (front) & $33(23-43)$ & $13(10-17)$ & $40(27-44)$ & $37(26-42)$ & $34(23-47)$ & $39(27-43)$ & $29(21-38)$ & $27(14-40)$ & $23(12-34)$ \\
\hline Lower leg (back) & $29(20-37)$ & $13(10-17)$ & $39(27-43)$ & $41(29-47)$ & $18(13-26)$ & $39(27-43)$ & $33(23-43)$ & $26(14-39)$ & 26 (14-39) \\
\hline Ambiant & $65(46-84)$ & $27(20-35)$ & $82(56-90)$ & $82(57-94)$ & $55(38-77)$ & $82(56-90)$ & $65(46-84)$ & $55(29-82)$ & $55(29-82)$ \\
\hline
\end{tabular}


b) Summer (June, July, August)

\begin{tabular}{|c|c|c|c|c|c|c|c|c|c|}
\hline & $\begin{array}{c}\text { Agricultural } \\
\text { workers }\end{array}$ & $\begin{array}{c}\text { Child care } \\
\text { workers }\end{array}$ & $\begin{array}{l}\text { Building } \\
\text { workers }\end{array}$ & $\begin{array}{l}\text { Landscapers, } \\
\text { gardeners }\end{array}$ & Mail carriers & Road workers & Horticulturists & $\begin{array}{c}\text { All workers } \\
\text { (erect) }\end{array}$ & $\begin{array}{c}\text { All workers } \\
\text { (bowing) }\end{array}$ \\
\hline Face & $32(24-41)$ & $15(11-23)$ & $40(29-44)$ & $28(20-32)$ & $32(26-46)$ & $38(28-43)$ & $24(18-31)$ & $30(16-44)$ & $12(6-17)$ \\
\hline Skull & $51(38-64)$ & $21(15-32)$ & $57(42-64)$ & $63(44-71)$ & $35(28-50)$ & $58(42-64)$ & $54(40-68)$ & $41(21-59)$ & $45(24-65)$ \\
\hline Forearm (external) & $47(35-59)$ & $17(12-26)$ & $47(34-52)$ & $54(38-61)$ & $37(30-53)$ & $47(34-52)$ & $47(35-60)$ & $32(17-47)$ & $41(22-60)$ \\
\hline Upper arm (external) & $45(34-57)$ & $16(11-24)$ & $44(32-50)$ & $53(37-61)$ & $31(25-44)$ & $45(33-50)$ & $47(35-60)$ & $30(16-43)$ & $41(21-59)$ \\
\hline Neck back & $58(43-74)$ & $24(17-37)$ & $65(47-72)$ & $75(53-85)$ & $37(29-52)$ & $65(48-73)$ & $65(48-82)$ & $45(24-65)$ & $56(29-80)$ \\
\hline Top of shoulders & $45(34-57)$ & $17(12-25)$ & $46(33-51)$ & $63(44-72)$ & $22(18-32)$ & $49(35-54)$ & $52(39-66)$ & $32(17-46)$ & $58(30-84)$ \\
\hline Shoulder & $54(41-69)$ & $22(16-33)$ & $59(43-66)$ & $61(43-69)$ & $42(34-59)$ & $59(43-66)$ & $53(40-67)$ & $42(22-61)$ & $43(22-62)$ \\
\hline Upper Leg (front) & $43(32-54)$ & $17(12-26)$ & $46(34-52)$ & $44(31-50)$ & 39 (31-56) & $46(33-51)$ & $38(29-49)$ & $33(17-48)$ & $28(15-41)$ \\
\hline Lower leg (back) & $37(28-47)$ & $17(12-26)$ & $46(33-51)$ & $49(35-56)$ & $21(17-30)$ & $46(33-51)$ & $43(32-54)$ & $32(17-47)$ & $33(17-47)$ \\
\hline Ambiant & $88(66-112)$ & $37(26-56)$ & $99(72-111)$ & $103(72-117)$ & 66 (53-94) & $99(72-111)$ & $88(66-112)$ & $71(37-103)$ & $71(37-103)$ \\
\hline
\end{tabular}


c) Autumn (September, October, November)

\begin{tabular}{|c|c|c|c|c|c|c|c|c|c|}
\hline & $\begin{array}{c}\text { Agricultural } \\
\text { workers }\end{array}$ & $\begin{array}{l}\text { Child care } \\
\text { workers }\end{array}$ & $\begin{array}{l}\text { Building } \\
\text { workers }\end{array}$ & $\begin{array}{c}\text { Landscapers, } \\
\text { gardeners }\end{array}$ & Mail carriers & Road workers & Horticulturists & $\begin{array}{l}\text { All } \\
\text { workers } \\
\text { (erect) }\end{array}$ & $\begin{array}{c}\text { All } \\
\text { workers } \\
\text { (bowing) }\end{array}$ \\
\hline Face & $16(11-20)$ & $6(3-8)$ & $23(14-28)$ & $16(13-21)$ & $19(14-25)$ & $22(14-27)$ & $13(8-16)$ & $16(8-24)$ & $7(3-11)$ \\
\hline Skull & $25(16-31)$ & $8(4-11)$ & $32(19-39)$ & $33(27-42)$ & $20(16-27)$ & $32(20-40)$ & $26(17-33)$ & $20(10-31)$ & $23(11-35)$ \\
\hline Forearm (external) & $23(15-29)$ & $6(3-9)$ & $27(16-33)$ & $29(24-37)$ & $21(17-28)$ & $27(16-33)$ & $23(15-29)$ & $17(8-25)$ & $21(10-32)$ \\
\hline Upper arm (external) & $22(15-28)$ & $6(3-8)$ & $25(15-31)$ & $28(23-36)$ & $18(14-24)$ & $26(16-31)$ & $23(15-29)$ & $15(7-24)$ & $21(10-32)$ \\
\hline Neck back & $28(18-35)$ & $9(5-12)$ & $36(22-44)$ & $39(32-50)$ & $21(16-28)$ & $36(22-45)$ & $31(20-39)$ & $23(11-35)$ & $27(13-42)$ \\
\hline Top of shoulders & $22(15-28)$ & $6(3-9)$ & $26(16-32)$ & $33(28-43)$ & $13(10-18)$ & $28(17-34)$ & $25(17-32)$ & $16(8-25)$ & $29(14-44)$ \\
\hline Shoulder & $26(17-33)$ & $8(4-11)$ & $33(20-41)$ & $32(27-41)$ & $24(18-32)$ & $33(20-41)$ & $26(17-32)$ & $21(10-32)$ & $21(10-33)$ \\
\hline Upper Leg (front) & $21(14-26)$ & $6(3-9)$ & $26(16-32)$ & $24(20-31)$ & $22(17-30)$ & $26(16-32)$ & $19(13-24)$ & $17(8-26)$ & $15(7-22)$ \\
\hline Lower leg (back) & $19(12-23)$ & 7 (4-9) & $26(16-32)$ & $27(22-34)$ & $13(10-17)$ & $26(16-32)$ & $21(14-26)$ & $17(8-25)$ & $17(8-26)$ \\
\hline Ambiant & $40(26-50)$ & $13(7-17)$ & $51(31-63)$ & $50(41-65)$ & $35(27-47)$ & $51(31-63)$ & $40(26-50)$ & $33(16-51)$ & $33(16-51)$ \\
\hline
\end{tabular}


d) Winter (December, January, February)

\begin{tabular}{|c|c|c|c|c|c|c|c|c|c|}
\hline & $\begin{array}{c}\text { Agricultural } \\
\text { workers }\end{array}$ & $\begin{array}{c}\text { Child care } \\
\text { workers }\end{array}$ & $\begin{array}{l}\text { Building } \\
\text { workers }\end{array}$ & $\begin{array}{c}\text { Landscapers, } \\
\text { gardeners }\end{array}$ & Mail carriers & Road workers & Horticulturists & $\begin{array}{c}\text { All } \\
\text { workers } \\
\text { (erect) }\end{array}$ & $\begin{array}{c}\text { All workers } \\
\text { (bowing) }\end{array}$ \\
\hline Face & $8(5-11)$ & $2(0-4)$ & $12(7-17)$ & $9(5-12)$ & $10(8-15)$ & $11(6-16)$ & $6(4-9)$ & $8(3-13)$ & $4(1-6)$ \\
\hline Skull & $12(8-17)$ & $2(1-5)$ & $16(9-24)$ & $18(11-24)$ & $11(8-16)$ & $17(9-24)$ & $13(8-18)$ & $11(4-17)$ & $12(5-19)$ \\
\hline Forearm (external) & $11(7-16)$ & $2(0-4)$ & $14(8-20)$ & $16(9-21)$ & $12(9-17)$ & $14(8-20)$ & $11(7-16)$ & $9(3-14)$ & $11(4-17)$ \\
\hline Upper arm (external) & $11(7-15)$ & $2(0-4)$ & $13(7-19)$ & $15(9-20)$ & $10(8-14)$ & $13(7-19)$ & $11(7-16)$ & $8(3-13)$ & $11(4-17)$ \\
\hline Neck back & $14(9-19)$ & $3(1-6)$ & $18(10-26)$ & $21(13-28)$ & $12(9-16)$ & $19(10-27)$ & $15(10-21)$ & $12(5-19)$ & $12(5-19)$ \\
\hline Top of shoulders & $11(7-15)$ & $2(0-4)$ & $13(7-19)$ & $18(11-24)$ & $8(6-11)$ & $14(8-20)$ & $13(8-17)$ & $8(3-14)$ & $15(6-24)$ \\
\hline Shoulder & $13(8-18)$ & $2(1-5)$ & $17(9-24)$ & $18(11-23)$ & $13(10-19)$ & $17(9-24)$ & $13(8-17)$ & $11(4-18)$ & $11(4-18)$ \\
\hline Upper Leg (front) & $11(7-14)$ & $2(0-4)$ & $14(7-19)$ & $13(8-17)$ & $12(9-17)$ & $13(7-19)$ & $10(6-13)$ & $9(3-14)$ & $8(3-12)$ \\
\hline Lower leg (back) & $9(6-13)$ & $2(0-4)$ & $13(7-19)$ & $14(9-19)$ & $7(5-10)$ & $13(7-19)$ & $11(7-14)$ & $9(3-14)$ & $9(3-14)$ \\
\hline Ambiant & $20(12-27)$ & $4(1-8)$ & $26(14-37)$ & $27(16-35)$ & $19(14-27)$ & $26(14-37)$ & $20(12-27)$ & $17(7-27)$ & $17(7-27)$ \\
\hline
\end{tabular}

